\title{
Comparison Study of the Adsorption of Copper Ions By Activated Carbon and A Locally Collected Bentonite
}

Emad A. S. AL-Hyali

Department of Chemistry

College of Education

University of Mosul
Abraheem A. M.

Department of Chemistry

College of Education

University of Dohok

\section{Alaa A. Azeez \\ Department of Chemistry / College of Education \\ University of Mosul}

Received
$21 / 07 / 2011$
Accepted

02 / $11 / 2011$

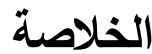

استخدم في هذه الدراسة نوع من البنتونايت المحلي والكاربون المنشط المحضر من زيوت

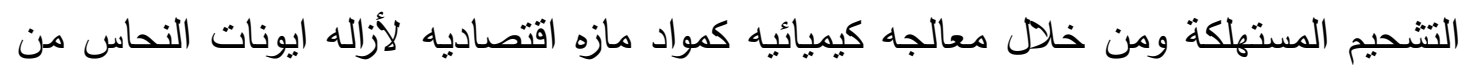
المحاليل المائية وبطريقه الدفعة الواحدة وعند تراكيز ودرجات حرارية مختلفة.

اشتمل هذا البحث على إجراء دراسة حركيه وثيرموديناميكيه باستخدام كلا المادتين

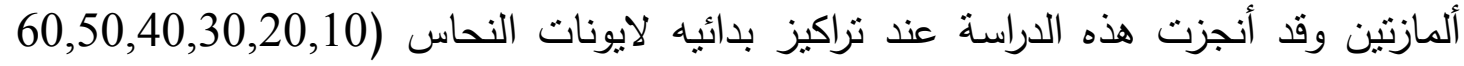

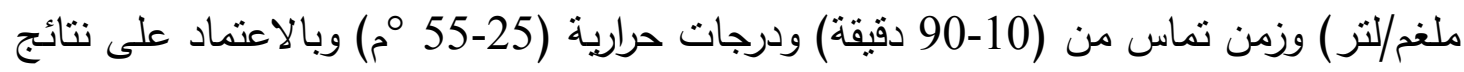
تأثثر درجه الحرارة حسبت الدوال الثيرموديناميكيه المادتين ألمازتين ومن مصدرين أولهما هو ثابت التوزيع للامتزاز (Kd) والذي يمثل النسبة بين

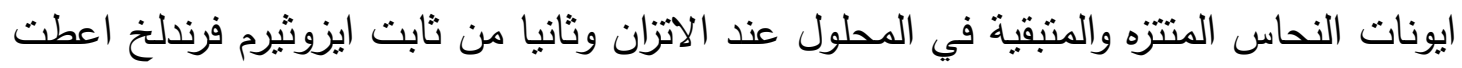
النتائج توافق بين كلا المصدرين.

كذاللك تضمن البحث تطبيق ايزوثيرمات فرندلخ ولانكمير على البيانات العملية للامتزاز وكان ايزوثيرم لانكمير أكثر انطباقا عمليا على النظام الددروس. وأظهرت النتائج إن امتزاز ايونات النحاس على البنتونايت كانت أفضل من الكاربون المنشط.

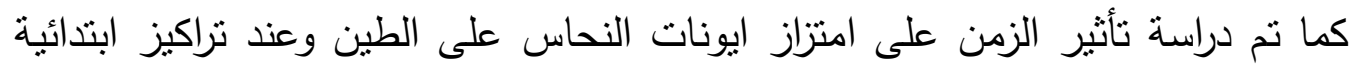

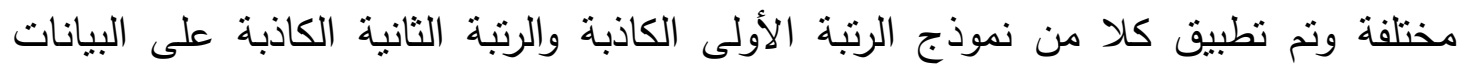


العمليه للاهتزاز وأظهرت النتائج إن معادلة الرتبة الثانية الكاذبة أكثر انطباقا من معادلة الرتبة

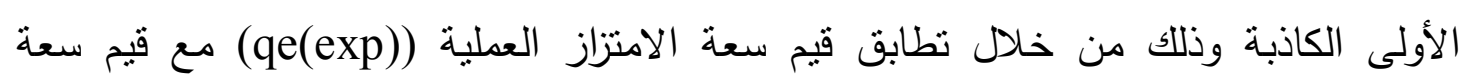

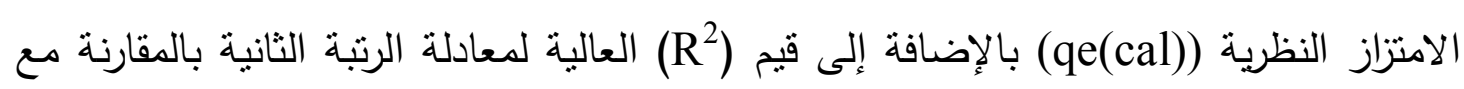

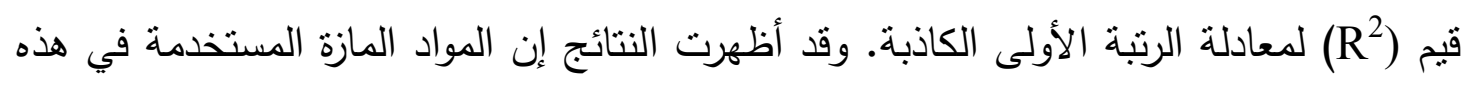

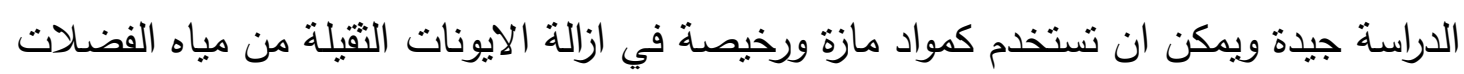
الصناعية.

\section{Abstract}

In this study, a locally collected bentonite and activated carbon (AC) synthesized from spent lubricant oils by chemical treatment were used as new non conventional and low cost adsorbents for the copper $\left(\mathrm{Cu}^{+2)}\right.$ ions adsorption in a batch mode at various initial concentrations and different temperatures. Systematic studies on $\mathrm{Cu}^{+2}$ ions adsorption equilibrium and kinetics by both adsorbents were carried out. The investigation were performed at different initial concentrations of $\mathrm{Cu}^{+2}$ ions $(10,20,30,40,50,60 \mathrm{mg} / \mathrm{L})$, contact time $(10-90 \mathrm{~min})$, and temperatures $\left(25-55^{\circ} \mathrm{C}\right)$.

Depending on the results of temperature effect, thermodynamic parameters $\left(\Delta \mathrm{G}^{\circ}, \Delta \mathrm{H}\right.$ and $\left.\Delta \mathrm{S}^{\circ}\right)$ were estimated from two sources. First; from the adsorption distribution constant $(\mathrm{Kd})$ which is represented by the ratio between the adsorbed and remained $\mathrm{Cu}^{+2}$ ions in solution at equilibrium and second, from Freundlich isotherm constant (Kf). Comparable results are obtained.

Freundlich and Langmuir isotherm models were applied to the adsorption data of the studied systems. The results obtained indicated that, the clay adsorbs $\mathrm{Cu}^{+2}$ ions more intense than $\mathrm{AC}$, with higher maximum adsorption capacity. Langmuir isotherm is better fitted to the adsorption data of the study system than Freundlich isotherm.

The effect of contact time data of $\mathrm{Cu}^{+2}$ ions adsorption onto clay, conducted at various initial concentrations were applied to pseudo first and second order kinetic models. The rate of adsorption was found to conform to pseudo second order kinetic with good correlation $\left(\mathrm{R}^{2}>0.99\right)$ and consistent values of the experimental (qe(exp)) and calculated (qe(cal)) adsorption capacities. The initial rate of adsorption was found to increase with initial concentration, where as the over all rate constant exhibited opposite variation. The employed adsorbents might be successfully used for the removal of other heavy metal ions from industrial wastewater.

\section{Introduction}

The presence of heavy metals in the environment has become a major threat to the plants, animals and human life due to their 
bioaccumulation tendency and toxicity. They are therefore must be removed from industrial effluents before discharge.

Clay is a natural, earthy, fine grained materials composed largely of a group of minerals .It has been used for thousands of years and they still keep their position, as very important industrial materials. Clays have also been used for chemical studies for various purposes, including the adsorption of various organic, inorganic substances, radioactive specimens and heavy metals [1,2].

Original clay, also termed as natural clay, is the product of weathering rocks and primarily consists of between 75 to $85 \%$ of montmorillonite. It has an excess of negative charge on its lattice and is characterized by a three layers structure with two silicate layers enveloping an aluminates layer [3].

In theory, the presence of a negative charge on the clay surface should affect the adsorbent's capacity to adsorb ions such that natural clay has an affinity for cationic species. Thus, it could be assumed that natural clay would have a greater capacity to adsorb basic substances than acidic. Ramakrishna et al. found that ,the bentonite clay exhibited high removals efficiency of a cationic dye (basic blue 9) reached to about $99.9 \%$ at acidic medium $(\mathrm{pH}=2)$ and exceeded $90 \%$ at other $\mathrm{pH}$ levels [4].

Clays can satisfy the various conditions of applications. The ion exchanges properties of clays have been intensively studied. The ion exchangers have a varying degree of preference. For instance, each metal ion depending on exchange type operating conditions and the metal being removed [5].

The mechanism by which the adsorption process takes place by clay is concerned mainly with the nature of forces acting between the adsorbed trace element and the adsorbent surface. According to the forces involved three basic kinds of adsorption can be distinguished as; physical, chemical and electrostatic adsorption [6].

The most widely used methods for removing heavy metals are chemical or electrochemical precipitation, both of which pose a significant problem in terms of disposal of the precipitated waste $[7,8]$, and ion exchange treatments, which do not appear to be economical [9].

It has been reported that some aquatic plants [10], wood materials, agricultural by products [11], clay natural zeolite and other adsorbents have the capacity to adsorb and accumulate heavy metals $[12,13]$. The need for low cost adsorbent is still vitals and attracting researcher's attention.

Adsorption of metal ions onto clay minerals is an interesting Topic and has been studied extensively. Both metal ions and clays are common components in nature and such study would provide useful information on the state of the metal ions and how they distribute in the environment. 
In addition, it can also enrich the knowledge of the adsorption process for the environmental remediation of the polluted heavy metal ions in water $[14,15]$.

The ability of clay minerals to adsorb heavy metal cations is an important property in the context of the increasing contamination of aquatic environments and soils by toxic wastes. Also sorption of metals on clays is becoming important for preparing clay catalysts.

Laboratory studies of the adsorption of heavy metals by clay have mostly been carried out using montmorillonite and illit. Several factors influence the adsorption efficiency of metal ions on clays, including salt concentration, $\mathrm{pH}$ of the solution, degree of loading on the adsorbent, presence of ligands and complex formation [16].

A wide range of methods is available for determination of the specific surface areas of clays. In general, these methods are of different reliability and accuracy. Vapor phase adsorption methods, using the nitrogen or rare gases at low temperatures, have been widely accepted as the most reliable methods $[17,18]$.

\section{Experimental \\ 1. Preparation of stock solution of $\mathrm{Cu}^{+2}$ ion}

An exact weight of copper nitrate $\mathrm{Cu}\left(\mathrm{NO}_{3}\right)_{2} .3 \mathrm{H}_{2} \mathrm{O}$ was dissolved in de-ionized water in a $250 \mathrm{ml}$ volumetric flask in order to prepare a solution of $1000 \mathrm{mg} / \mathrm{L}$ concentration. The prepared sample was kept in a reagent bottle and used for preparing other solutions.

\section{Effect of concentration}

The experiments were achieved in batch mode. $50 \mathrm{ml}$ of $\mathrm{Cu}^{+2}$ ion solution of different concentrations (10, 20, 30, 40, 50 and 60) $\mathrm{mg} / \mathrm{L}$ was put in six dry and closed flasks in sequence. $0.1 \mathrm{~g}$ from the adsorbent was added to each flask. The solutions were shacked for $70 \mathrm{~min}$ with speed of $140 \mathrm{rpm}$ at $25^{\circ} \mathrm{C}$. The solutions were then filtered, and the amount of adsorbed substance was determined by (Perkins Elmer, Analyst 200) atomic absorption (AA) spectrophotometer.

\section{Effect of temperature}

The same steps those followed in finding the effect of concentration were repeated here with using the same concentration and keeping other conditions constant but under various temperatures $(25,35$, 45 , and 55) ${ }^{\circ} \mathrm{C}$.

\section{Adsorbent}

Two types of adsorbents are used for this study, a local bentonite and a synthesized activated carbon as follow: 


\subsection{Activated carbon}

The activated carbon used in this investigation is supplied by another group of our research work [19]. This carbon was synthesized from spent lubricant oil by chemical treatment. The properties of the prepared carbon were tested in terms of its capacity to adsorb the iodine, methylene blue dye and by other properties. These properties could be summarized as follow: adsorption capacity of methylene blue is 300 $\mathrm{mg} / \mathrm{g}$, iodine number $950 \mathrm{mg} / \mathrm{g}$, moisture $9.85 \%$, ash content $1.52 \%$ and density $0.3904 \mathrm{~g} / \mathrm{cm}^{3}$.

\subsection{Clay}

The clay used in this study is a type of bentonite. It was bought from the local market of the city center of Mosul. Its commercial name is known as Khawa clay, and is originally collected from the north part of Mosul. The chemical composition of the raw clay was obtained by AA and XRF analysis and listed in Table (1).

Table (1): Chemical composition of the raw clay obtained by AA and XRF analysis

\begin{tabular}{|c|c|c|c|}
\hline Mineral & $\%$ & Metals oxide & $\%$ \\
\hline Chlorite & 15.62 & $\mathrm{SiO}_{2}$ & 23.00 \\
\hline Illite & 26.06 & $\mathrm{TiO}_{2}$ & 0.23 \\
\hline Chlorite+Caolinite & 9.63 & $\mathrm{Al}_{2} \mathrm{O}_{3}$ & 5.02 \\
\hline Quartz & 13.81 & $\mathrm{FeO}+\mathrm{Fe}_{2} \mathrm{O}_{3}$ & 6.00 \\
\hline Philspar & 4.06 & $\mathrm{MnO}$ & 0.10 \\
\hline Calcite & 23.33 & $\mathrm{MgO}$ & 22.57 \\
\hline Illite+Chlorite & 7.45 & $\mathrm{CaO}$ & 10.33 \\
\hline & & $\mathrm{Na}_{2} \mathrm{O}$ & 0.16 \\
\hline & & $\mathrm{K}_{2} \mathrm{O}$ & 0.08 \\
\hline & & $\mathrm{P}_{2} \mathrm{O}_{5}$ & 0.007 \\
\hline & & $\mathrm{H}_{2} \mathrm{O}_{+} \mathrm{CO}_{2}$ & 23.00 \\
\hline Total & 99.96 & $\mathrm{Total}$ & 100.49 \\
\hline
\end{tabular}

\subsubsection{Preparation of the clay sample}

The raw material was first crushed and washed with distil water in order to remove all impurities, and then dried under $100{ }^{\circ} \mathrm{C}$ for 6 hours. The clay was ground again and a colloidal suspension was made. The heavy particles were discarded by decantation. The suspension was then filtered and the resulting fine particles of the clay were left overnight in an oven under $100{ }^{\circ} \mathrm{C}$ and finally ground and particles of sizes in the range of 70$150 \mu \mathrm{m}$ were separated by using standard ASTM molecular sieves and used as adsorbent.

\section{Adsorption isotherm}

Batch experiments were carried out in $250 \mathrm{ml}$ closed conical flasks at $25^{\circ} \mathrm{C}$ for 70 minutes. $0.1 \mathrm{~g}$ of the adsorbent (clay or carbon) was 
thoroughly mixed with $50 \mathrm{ml}$ of $\mathrm{Cu}^{+2}$ ions solutions of different concentrations $(10,20,30,40,50) \mathrm{mg} / \mathrm{L}$. After shaking the flasks for 70 min with agitation rate of $140 \mathrm{rpm}$, the adsorbate was isolated from the reaction mixture by filtration. The concentration of the residual $\mathrm{Cu}^{+2}$ ions in solution is determined by atomic absorption spectroscopy.

The above experiment was repeated at different temperatures $(25$, $35,45$, and 55$)^{\circ} \mathrm{C}$. The amount of $\mathrm{Cu}^{+2}$ ions adsorbed at equilibrium onto adsorbent surface, qe $(\mathrm{mg} / \mathrm{g})$, was calculated by the following mass balance relationship:

$$
q e=\frac{C i-\dot{C} e}{m} * \frac{v}{1000}
$$

Where $\mathrm{Ci}$ and $\mathrm{Ce}$ are initial concentration and equilibrium liquid phase concentration of $\mathrm{Cu}^{+2}$ ions $(\mathrm{mg} / \mathrm{L})$, respectively, $\mathrm{V}$ is the volume of solution (L) and $m$ is the weight of the adsorbent used.

\section{Effect of time}

The effect of time variation on the adsorption efficiency of $\mathrm{Cu}^{+2}$ ions on clay is investigated by conducting the same experimental concentration of copper ions and the amount of clay at constant temperature, while the time is varied between 10-90 minutes.

\section{RESULTS AND DISCUSSION}

All the experiments of the studied systems were carried out as batch method for single component. The results of this investigation were used for comparison with the data obtained by employing the synthesized activated carbon as adsorbent for the adsorption of $\mathrm{Cu}^{+2}$ ions under the same conditions. The main objective of this research work is to find a cheap and effective adsorbent for industrial wastewater treatment [18, 26]. The performance of this goal could be achieved through thermodynamic and kinetic studies by which the nature of the studied system, forces controlling the adsorption process, and the mechanism of the attachment of $\mathrm{Cu}^{+2}$ ions on the adsorbent surface can be determined.

\section{Effect of contact time}

The effect of contact time is investigated at various initial concentrations $(10-60 \mathrm{mg} / \mathrm{L})$ at constant temperature $\left(25^{\circ} \mathrm{C}\right)$ in terms of adsorption capacity. The variation of adsorption capacities of clay to adsorb the $\mathrm{Cu}^{+2}$ ions are presented in Table (2) and illustrated in Figure (1).

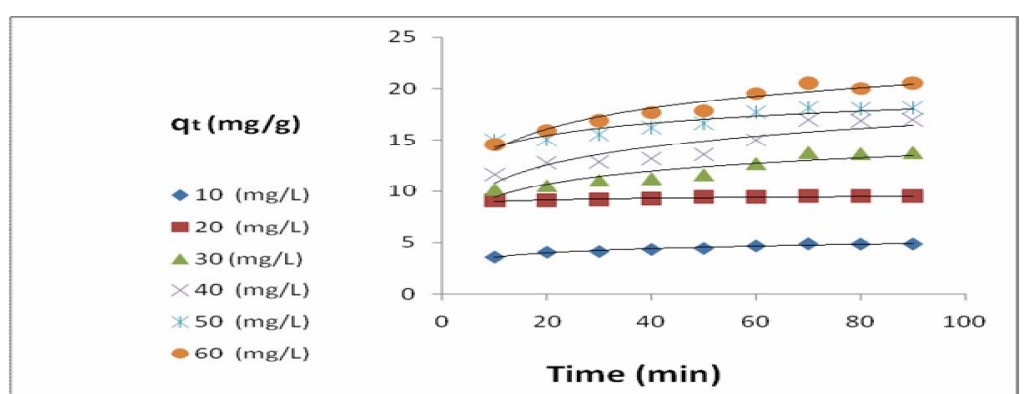

Figure 1: Variation of adsorption capacity of clay with time 
Table (2): Effect of contact time on the capacity adsorption at initial concentration

\begin{tabular}{|c|c|c|c|c|c|c|}
\hline $\begin{array}{c}\text { Time } \\
(\mathrm{min})\end{array}$ & $\begin{array}{c}\mathrm{qt} \\
10 \mathrm{mg} / \mathrm{L}\end{array}$ & $\begin{array}{c}\mathrm{qt} \\
20 \mathrm{mg} / \mathrm{L}\end{array}$ & $\begin{array}{c}\mathrm{qt} \\
30 \mathrm{mg} / \mathrm{L}\end{array}$ & $\begin{array}{c}\mathrm{qt} \\
40 \mathrm{mg} / \mathrm{L}\end{array}$ & $\begin{array}{c}\mathrm{qt} \\
50 \mathrm{mg} / \mathrm{L}\end{array}$ & $\begin{array}{c}\mathrm{qt} \\
60 \mathrm{mg} / \mathrm{L}\end{array}$ \\
\hline 10 & 3.59 & 9.09 & 10.11 & 11.64 & 14.97 & 14.52 \\
\hline 20 & 4.07 & 9.10 & 10.48 & 12.79 & 15.05 & 15.89 \\
\hline 30 & 4.13 & 9.16 & 11.03 & 12.86 & 15.54 & 16.81 \\
\hline 40 & 4.34 & 9.24 & 11.18 & 13.20 & 16.19 & 17.59 \\
\hline 50 & 4.44 & 9.39 & 11.57 & 13.61 & 16.58 & 17.77 \\
\hline 60 & 4.68 & 9.43 & 12.67 & 15.02 & 17.65 & 19.50 \\
\hline 70 & 4.89 & 9.48 & 13.75 & 16.93 & 18.05 & 20.53 \\
\hline 80 & 4.86 & 9.46 & 13.65 & 16.82 & 17.96 & 20.33 \\
\hline 90 & 4.87 & 9.48 & 13.74 & 16.90 & 18.06 & 20.51 \\
\hline
\end{tabular}

The results of Table (2) and Figure (1) show that at certain initial concentration, the adsorption capacity is increased rapidly in the first 10 minutes indicating a high rate of uptake level. The rate of removal is then gradually decreased with time and reached to equilibrium within 70 minutes. The kinetic study is performed for the first 50 minutes, while equilibrium time is considered at 70 minutes.

The investigation also revealed that, at certain time the number of $\mathrm{mg}$ of $\mathrm{Cu}^{+2}$ ions per gram of clay is increased with increased of initial concentration. This is due to the increase of mass transfer into the solid surface with the increase of initial concentration.

\section{Effect of temperature}

The effect of temperature on adsorption process provides valuable information related to the nature of the system under consideration and determines the kind of attraction forces between the adsorbate and adsorbent surface.

In this work, the effect of varying temperature on the adsorption of $\mathrm{Cu}^{+2}$ ions on both clay and activated carbon is investigated in the range of $25-55{ }^{\circ} \mathrm{C}$ and at various concentrations. The adsorption efficiency is estimated in terms of adsorption ratio (\%Ads.) according to the following equation:

$$
\% \text { Ads. }=\frac{\text { Cads. }}{C e} * 100
$$

Where as Cads and $\mathrm{Ce}(\mathrm{mg} / \mathrm{L})$ are the concentrations of the adsorbed and remained $\mathrm{Cu}^{+2}$ ions in the solution at equilibrium respectively. The obtained results are listed in Table (3)

Table (3): Effect of temperature on the adsorption efficiency of $\mathrm{Cu}$ (II) onto clay and activated carbon

\begin{tabular}{|c|c|c|c|c|c|c|c|}
\hline \multirow[b]{2}{*}{ TEMP. ${ }^{\mathrm{T}} \mathrm{C}$} & \multicolumn{7}{|c|}{$\%$ ADS. OF Cu $\mathbf{C u}^{+2}$ AT CONCENTATION ( Mg.L L $\left.^{-1}\right)$} \\
\hline & 10 & 20 & 30 & 40 & 50 & 60 & \multirow{5}{*}{ clay } \\
\hline 25 & $91 \%$ & $89 \%$ & $82 \%$ & $74 \%$ & $62 \%$ & $51 \%$ & \\
\hline 35 & $85 \%$ & $81 \%$ & $71 \%$ & $62 \%$ & $59 \%$ & $49 \%$ & \\
\hline 45 & $81 \%$ & $73 \%$ & $64 \%$ & $56 \%$ & $53 \%$ & $48 \%$ & \\
\hline 55 & $74 \%$ & $71 \%$ & $60 \%$ & $55 \%$ & $53 \%$ & $44 \%$ & \\
\hline 25 & $75 \%$ & $57 \%$ & $45 \%$ & $32 \%$ & $31 \%$ & $26 \%$ & \multirow{4}{*}{$\begin{array}{c}\text { Activated } \\
\text { carbon }\end{array}$} \\
\hline 35 & $50 \%$ & $43 \%$ & $37 \%$ & $30 \%$ & $27 \%$ & $21 \%$ & \\
\hline 45 & $46 \%$ & $36 \%$ & $34 \%$ & $28 \%$ & $23 \%$ & $12 \%$ & \\
\hline 55 & $41 \%$ & $35 \%$ & $32 \%$ & $26 \%$ & $20 \%$ & $11 \%$ & \\
\hline
\end{tabular}


The results of Table (3) showed similar trend of variation of adsorption of $\mathrm{Cu}^{+2}$ ions on clay and carbon in which at certain concentration the adsorption efficiencies decreased with increasing temperature indicating to the physical nature of adsorption. At a specific temperature, the adsorption efficiencies decreased with increasing concentration. This could due to the increase of $\mathrm{Cu}^{+2}$ ions competition to be attached on a definite number of active sites available on the surface of a certain amount of adsorbent. The study of temperature effect facilitated the estimation of thermodynamic parameters of the adsorption system.

\section{Thermodynamic study}

The thermodynamic parameters of adsorption are good measures of direction of the process, nature of forces controlling it and order of adsorption system, which occur as a result of various intra and inter molecular forces those responsible for the attachment of adsorbate onto the surface of solid adsorbent. The thermodynamic parameters of adsorption of $\mathrm{Cu}^{+2}$ ions onto clay and activated carbon including $\Delta \mathrm{G}^{\circ}$ $(\mathrm{kJ} / \mathrm{mol}), \Delta \mathrm{H}(\mathrm{kJ} / \mathrm{mol}), \Delta \mathrm{S}^{\circ}(\mathrm{J} / \mathrm{mol} . \mathrm{K})$ are evaluated by employing the following equations [27].

$$
\begin{aligned}
& \Delta \mathbf{G}^{\circ}=-\mathbf{R T} \mathbf{L} \mathbf{K}_{\mathbf{d}} \\
& L n K d=-\frac{\Delta \mathrm{H}}{\mathrm{RT}}+\text { constant } \\
& \Delta \mathbf{G}^{\circ}=\Delta \mathbf{H}-\mathbf{T} \Delta \mathbf{S}^{\circ}
\end{aligned}
$$

Where $\mathrm{T}$ is the temperature in Kelvin and $\mathrm{R}$ is the universal gas constant $(8.314 \mathrm{~J} / \mathrm{mol} . \mathrm{K}), \mathrm{K}_{\mathrm{d}}$ is the adsorption distribution constant. In this work the $K_{d}$ value is calculated from two sources; in the first one, the $K_{d}$ is considered as equilibrium constant of the adsorption process and determined from the ratio of the concentration of adsorbate on the solid surface $(\mathrm{Cads} . \mathrm{mg} / \mathrm{L})$ and in the solution $(\mathrm{Ce}, \mathrm{mg} / \mathrm{L})$ at equilibrium.

$$
K_{\mathbf{d}}=\text { Cads / Ce }
$$

According to this equation the values of $\mathrm{K}_{\mathrm{d}}$ is estimated at various initial concentrations, $(10,20$ and $30 \mathrm{mg} / \mathrm{L})$ and in the range of temperatures (298-328 K.). By applying Vant Hoff equation (equ. 4), plots of $\mathrm{Ln} \mathrm{K}_{\mathrm{d}}$ against the reciprocal temperature gave straight lines (Figures (2) and (3)). The values of $\Delta \mathrm{H}$ are calculated from their slopes. Equations (3) and (5) are used for the determination of $\Delta \mathrm{G}^{\circ}$ and $\Delta \mathrm{S}^{\circ}$ values respectively. The values of $\mathrm{K}_{\mathrm{d}}, \Delta \mathrm{G}^{\circ}, \Delta \mathrm{H}$ and $\Delta \mathrm{S}^{\circ}$ obtained from the adsorption data of $\mathrm{Cu}^{+2}$ ions on clay and activated carbon are listed in Table (4).

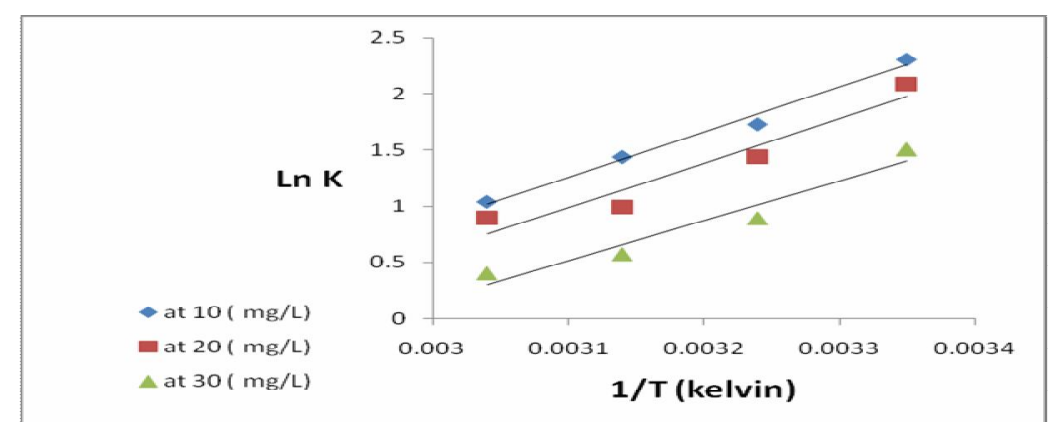

Figure (2): The relationship between $\operatorname{LnK}_{d}$ and 1/T of clay at different concentrations 


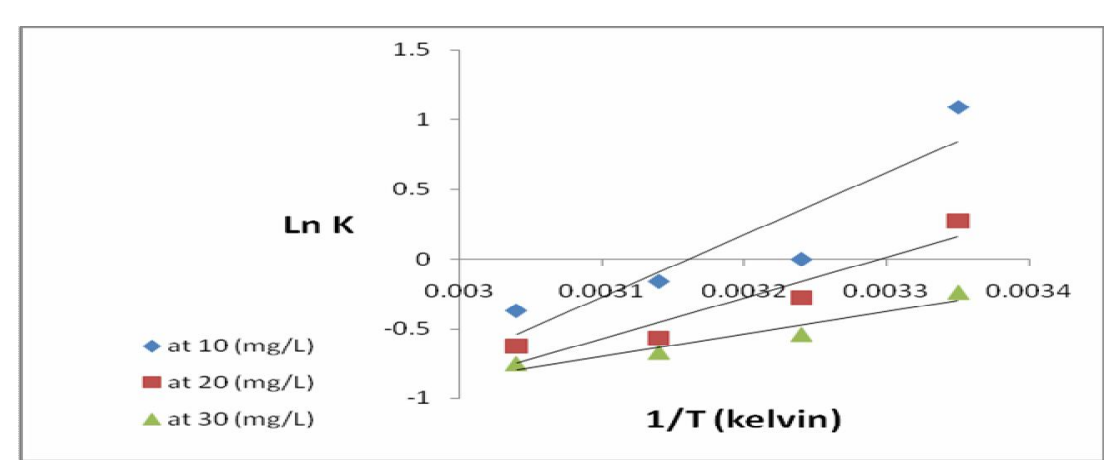

Figure (3): The relationship between $\operatorname{LnK}_{d}$ and 1/T of activated carbon at different concentrations

Table (4): Thermodynamic parameters of adsorption of $\mathrm{Cu}^{+2}$ ions on clay and activated carbon calculated from considering $K$ as the equilibrium constant

\begin{tabular}{|c|c|c|c|c|c|c|}
\hline Adsorbent & Conc & $\begin{array}{l}\text { Temp. } \\
{ }^{\circ} \mathrm{K}\end{array}$ & $\mathrm{K}$ & $\Delta \mathrm{H}\left(\mathrm{kJ} \cdot \mathrm{mol}^{-1}\right)$ & $\Delta \mathrm{G}^{\circ}\left(\mathrm{kJ} \cdot \mathrm{mol}^{-1}\right)$ & $\Delta \mathrm{S}\left(\mathrm{J} \cdot \mathrm{mol}^{-1} \cdot \mathrm{K}^{-1}\right)$ \\
\hline \multirow{12}{*}{ Clay } & \multirow{4}{*}{$10 \mathrm{mg} / \mathrm{L}$} & 298 & 10.11 & \multirow{4}{*}{-33.17} & -5.72 & -92.10 \\
\hline & & 308 & 5.66 & & -4.43 & -93.31 \\
\hline & & 318 & 4.26 & & -3.80 & -92.34 \\
\hline & & 328 & 2.84 & & -2.83 & -92.48 \\
\hline & \multirow{4}{*}{$20 \mathrm{mg} / \mathrm{L}$} & 298 & 8.09 & \multirow{4}{*}{-32.87} & -5.17 & -92.93 \\
\hline & & 303 & 4.26 & & -3.68 & -94.75 \\
\hline & & 318 & 2.70 & & -2.61 & -95.14 \\
\hline & & 328 & 2.44 & & -2.42 & -92.82 \\
\hline & \multirow{4}{*}{$30 \mathrm{mg} / \mathrm{L}$} & 298 & 4.55 & \multirow{4}{*}{-29.63} & -3.74 & -86.87 \\
\hline & & 303 & 2.44 & & -2.27 & -81.40 \\
\hline & & 318 & 1.77 & & -1.50 & -88.44 \\
\hline & & 328 & 1.50 & & -1.09 & -87.01 \\
\hline \multirow{12}{*}{$\begin{array}{c}\text { Activated } \\
\text { carbon }\end{array}$} & \multirow{4}{*}{$10 \mathrm{mg} / \mathrm{L}$} & 298 & 3.00 & \multirow{4}{*}{-37.047} & -2.700 & -115.2 \\
\hline & & 308 & 1.00 & & 0.00 & -120.2 \\
\hline & & 318 & 0.85 & & 0.423 & -117.8 \\
\hline & & 328 & 0.69 & & 1.008 & -116.0 \\
\hline & \multirow{4}{*}{$20 \mathrm{mg} / \mathrm{L}$} & 298 & 1.32 & \multirow{4}{*}{-24.310} & -0.668 & -79.3 \\
\hline & & 303 & 0.75 & & 0.716 & -81.2 \\
\hline & & 318 & 0.56 & & 1.506 & -81.1 \\
\hline & & 328 & 0.53 & & 1.718 & -79.3 \\
\hline & \multirow{4}{*}{$30 \mathrm{mg} / \mathrm{L}$} & 298 & 0.78 & \multirow{4}{*}{-13.485} & 0.594 & -47.2 \\
\hline & & 303 & 0.58 & & 1.382 & -48.2 \\
\hline & & 318 & 0.51 & & 1.771 & -47.9 \\
\hline & & 328 & 0.47 & & 2.045 & -47.3 \\
\hline
\end{tabular}

In the second attempt, the thermodynamic parameters are calculated from considering the Freundlich constant $\left(\mathrm{K}_{\mathrm{F}}\right)$ as a representative of the adsorption distribution constant $\left(\mathrm{K}_{\mathrm{d}}\right)$ [27]. In this case, the thermodynamic parameters are determined for the range of concentration employed for fitting the adsorption data on this isotherm (10-60 mg/L) and at different temperatures (298 -328 K). Equations (3-5), are then used for the estimation of the values of $\Delta \mathrm{G}^{\circ}, \Delta \mathrm{H}$ and $\Delta \mathrm{S}^{\circ}$. The 
relation between LnK and 1/T are shown in Figure (4). The obtained values from this application are listed in Table (5).

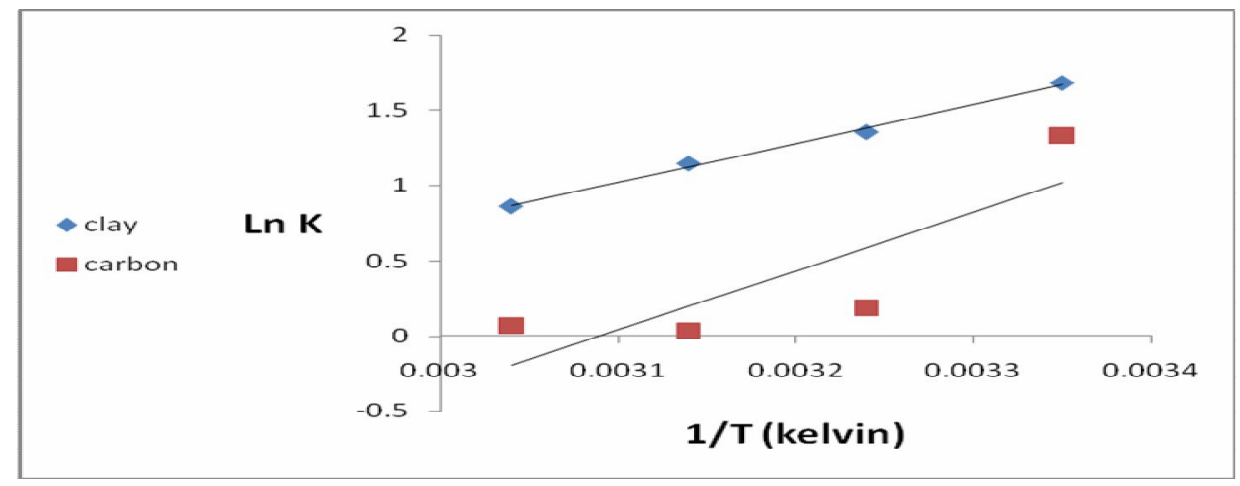

Figure (4): The relationship between $\mathrm{Ln} \mathrm{Kd}$ and $1 \backslash \mathrm{T}$ of clay and activated carbon by using Freundlich constant

Table (5): Thermodynamic parameters of adsorption of $\mathrm{Cu}^{+2}$ ions on clay and activated carbon by using Freundlich constant

\begin{tabular}{|c|c|c|c|c|c|}
\hline adsorbent & $\underset{\mathbf{0}}{\text { Temp. }}$ & $\mathbf{K}_{\mathbf{F}}$ & $\Delta \mathbf{H}\left(\mathbf{k J} . \mathrm{mol}^{-1}\right)$ & $\Delta G^{\circ}\left(\mathrm{kJ} \mathrm{mol}^{-1}\right)$ & $\Delta \mathrm{S}\left(\mathrm{JJmol}^{-1} \cdot \mathrm{K}^{-1}\right)$ \\
\hline \multirow{4}{*}{ Clay } & 298 & 5.35 & \multirow{4}{*}{-21.425} & -4.155 & -57.95 \\
\hline & 308 & 3.88 & & -3.471 & -58.29 \\
\hline & 318 & 3.15 & & -3.033 & -57.83 \\
\hline & 328 & 2.37 & & -2.353 & -58.14 \\
\hline \multirow{4}{*}{$\begin{array}{l}\text { Activated } \\
\text { carbon }\end{array}$} & 298 & 3.79 & \multirow{4}{*}{-32.374} & -3.301 & -97.56 \\
\hline & 308 & 1.20 & & -0.466 & -103.35 \\
\hline & 318 & 1.03 & & -0.078 & -101.55 \\
\hline & 328 & 1.07 & & -0.184 & -98.14 \\
\hline
\end{tabular}

Looking at the results of Tables (4) and (5), the obtained thermodynamic parameters agree in that, the adsorption processes of $\mathrm{Cu}^{+2}$ ions onto clay and activated carbon are spontaneous processes, exothermic and physical forces controlling the adsorption process leading to increasing the order of the studied system.

Comparison between the values of the thermodynamic parameters obtained when employing $\mathrm{K}_{\mathrm{d}}$ (Table 4 ) and $\mathrm{K}_{\mathrm{F}}$ (Table 5) by using clay as adsorbent and then activated carbon, showed identical observations. The values of $\Delta \mathrm{G}^{\circ}$ and $\Delta \mathrm{S}^{\circ}$ were found to vary in the same range. The values of $\Delta \mathrm{H}(21.425 \mathrm{~kJ} / \mathrm{mol})$ obtained by using $\mathrm{K}_{\mathrm{F}}$ values when applying the Freundlich isotherm on the adsorption data in the range of concentrations $(10-60 \mathrm{mg} / \mathrm{L})$ were less than that, obtained from the average of $\Delta \mathrm{H}$ 
values $(31.89 \mathrm{KJ} /$ mole $)$ determined at three initial concentrations $(10,20$ and $30 \mathrm{mg} / \mathrm{L}$ ), when $K_{d}$ is considered as the equilibrium constant of adsorption. This difference may due to the range of concentration considered in both methods. The values of $\Delta \mathrm{H}$ obtained at different initial concentrations indicted that the released heat is decreased with increasing the initial concentration which results from the increase of competition among $\mathrm{Cu}^{+2}$ ions to be adsorbed on the clay surface that leading to weakening the forces of attachment between $\mathrm{Cu}^{+2}$ ions and clay surface. Therefore, estimation of the $\Delta \mathrm{H}$ values at higher initial concentrations to reach the same range of that employed for the application of Freundlich isotherm $(10-60 \mathrm{mg} / \mathrm{L})$ may give lower values of $\Delta \mathrm{H}$ and then the average value of $\Delta \mathrm{H}$ would be consistent with that obtained from employing $\mathrm{K}_{\mathrm{F}}$ for the thermodynamic parameter calculations. Similar trend of variation is noticed when activated carbon is used as adsorbent.

A conclusion can be derived from this study in which, both values of the equilibrium and the Freundlich constants can be used for the determination of the thermodynamic parameters of adsorption and identical results could be obtained if similar range of temperatures and initial concentrations are considered. The difference between the two methods is that, the use of Freundlich constant provides average values of information where as the other method gives more detailed information and illustrates the variation of the behavior of the adsorption system at each initial concentration, which could be valuable for determining the optimum conditions of the adsorption system and give better understanding by which the mechanism of adsorption occurred.

\section{Adsorption Isotherm}

Equilibrium relationships between adsorbent and adsorbate are usually described by adsorption isotherms. This relationship is expressed in terms of the ratio between the quantity of adsorbed and that remaining solute in the solution at fixed temperature at equilibrium.

The adsorption isotherm is important from both the theoretical and practical point of view. Therefore, several isotherm equations are available in the literature which can be used for analyzing experimental adsorption equilibrium data. Parameters of these various models can provide information illustrating the adsorption mechanism, the surface properties and affinities of the adsorbent.

Two of the most common adsorption isotherms for single solute system, the Langmuir and Freundlich models, are used to test the fitting of the adsorption data of $\mathrm{Cu}^{+2}$ ions on clay and activated carbon at various temperatures. The applicability of the equations was judged by the value of correlation coefficients.

\section{Freundlich isotherm}

This isotherm is the earliest model used for describing the adsorption process [20]. It is an empirical equation that can be applied to 
non-ideal adsorption system involving heterogeneous surfaces with interaction between adsorbed molecules. It also suggests that, the adsorption energy is exponentially decreased on completion of the adsorption sites of an adsorbent. The linear form of Freundlich isotherm can be represented as follow.

\section{$\operatorname{Lnqe}=\operatorname{Ln~} K_{\mathrm{F}}+1 / \mathrm{n} \quad \operatorname{LnCe}$}

Where $\mathrm{q}_{\mathrm{e}}(\mathrm{mg} / \mathrm{g})$ is the amount of adsorbed $\mathrm{Cu}^{+2}$ ions on the adsorbent at equilibrium, $\mathrm{K}_{\mathrm{F}}(\mathrm{L} / \mathrm{g})$ and $\mathrm{n}$ are constants related to the adsorption capacity and adsorption intensity respectively. The values of $\mathrm{K}_{\mathrm{F}}$ and $\mathrm{n}$ are calculated from the intercept and the slope of the plot of $\mathrm{Ln}$ $\mathrm{q}_{\mathrm{e}}$ against $\mathrm{Ln} \mathrm{Ce}$ respectively. These values were estimated at various temperatures. Comparison between the Freundlich parameters of the adsorption of $\mathrm{Cu}^{+2}$ ion on clay and activated carbon are listed in Table (6).

Table (6): Results of the application of Freundlich and Langmuir isotherms on the adsorption of ion copper on the clay and activated carbon

\begin{tabular}{|c|c|c|c|c|c|c|c|}
\hline \multirow{2}{*}{ Temp. ${ }^{\circ} \mathrm{C}$} & \multicolumn{3}{|c|}{ Freundlich } & \multicolumn{3}{c|}{ Langmuir } & \multirow{2}{*}{ Adsorbent } \\
\cline { 2 - 7 } & $\mathrm{K}_{\mathrm{F}}$ & $\mathrm{n}$ & $\mathrm{R}^{2}$ & $\mathrm{Q}_{\max }(\mathrm{mg} / \mathrm{g})$ & $\mathrm{b}(\mathrm{L} / \mathrm{mg})$ & $\mathrm{R}^{2}$ & \multirow{2}{*}{ clay } \\
\hline 25 & 5.35 & 2.42 & 0.881 & 17.54 & 0.442 & 0.998 & \\
\hline 35 & 3.88 & 2.23 & 0.965 & 17.85 & 0.196 & 0.985 & \\
\hline 45 & 3.15 & 2.18 & 0.989 & 16.12 & 0.153 & 0.980 & \\
\hline 55 & 2.37 & 1.83 & 0.972 & 18.51 & 0.094 & 0.967 & \\
\hline 25 & 3.79 & 3.96 & 0.923 & 8.00 & 0.295 & 0.975 & \multirow{2}{*}{$\begin{array}{l}\text { Activated } \\
\text { carbon }\end{array}$} \\
\hline 35 & 1.20 & 2.03 & 0.969 & 9.01 & 0.078 & 0.995 & \\
\hline 45 & 1.03 & 2.01 & 0.959 & 7.93 & 0.075 & 0.981 & \\
\hline 55 & 1.07 & 2.01 & 0.908 & 6.84 & 0.085 & 0.962 & \\
\hline
\end{tabular}

The results of Table (6) showed good fit of the Freundlich isotherm on the adsorption data of $\mathrm{Cu}^{+2}$ ions on clay $\left(\mathrm{R}^{2}=0.88-0.98\right)$ and carbon $\left(\mathrm{R}^{2}=0.90-0.96\right)$ (see Figure (5)). According to this isotherm the capacity of clay $\left(\mathrm{K}_{\mathrm{F}}=2.37-5.35\right)$ to adsorb $\mathrm{Cu}^{+2}$ ions is higher than that of carbon $\left(\mathrm{K}_{\mathrm{F}}=1.07-3.79\right)$. Where as adsorption of $\mathrm{Cu}^{+2}$ ions onto clay is more intense $(n=1.83-2.42)$ than that onto activated carbon $(n=2.01-3.96)$.

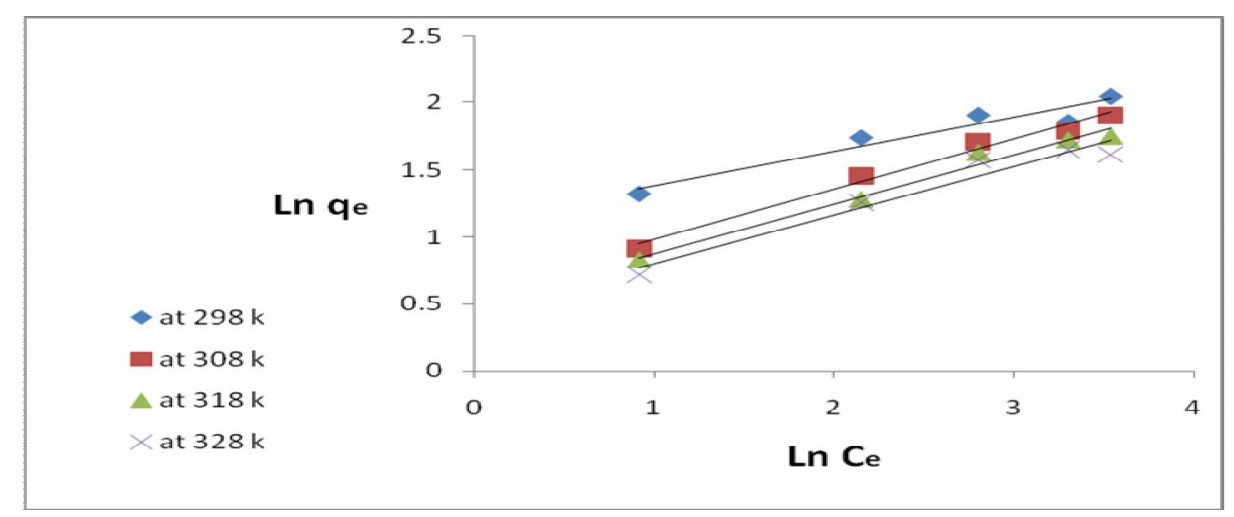

Figures (5): The relationship between Ln qe versus Ln Ceq at various temperatures on activated carbon 


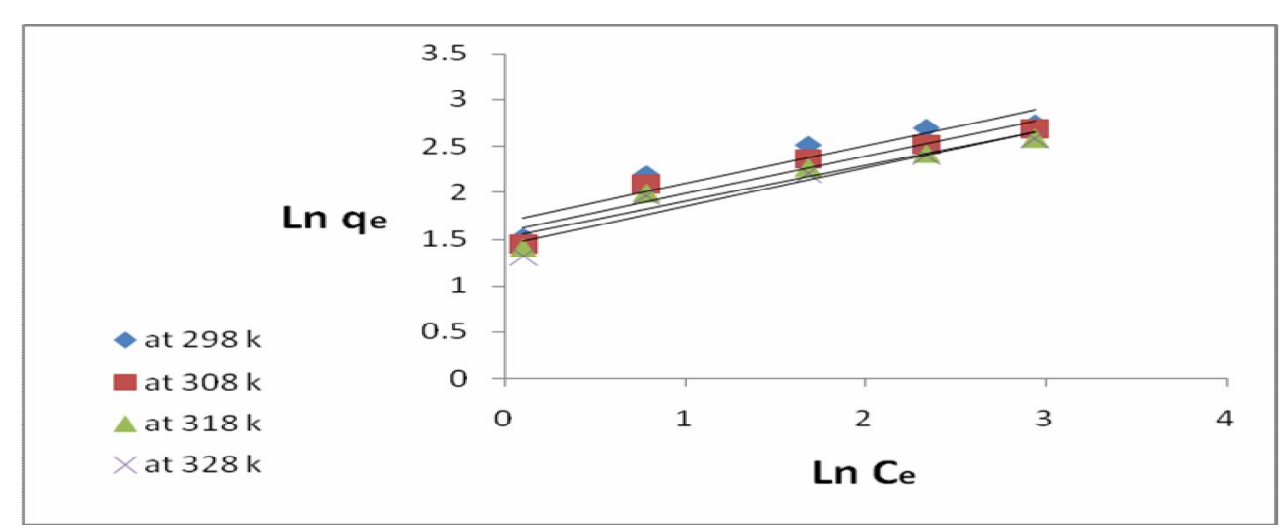

Figures (6): The relationship between Ln qe versus Ln Ceq at various temperatures on clay

\section{Langmuir isotherm}

This isotherm is valid for adsorption of a solute from a liquid solution as monolayer adsorption on a surface containing a finite number of identical sites [21].

The Langmuir isotherm assumes that, the adsorption take place at specific homogeneous sites within the adsorbent, and once a copper ion occupies a site, the adsorbent has a finite capacity for the adsorbate at equilibrium. All sites are supposed to be identical and energetically equivalent. The assumption of the uniform energies of adsorption onto the adsorbent surface without the migration of the adsorbate molecules within the plane of this surface helped for the estimation of the maximum adsorption capacity corresponding to complete monolayer coverage on the adsorbent surface. The linear form of Langmuir isotherm can be expressed as in the following equation:

$\frac{C e}{q e}=\frac{1}{b Q \max }+\frac{C e}{Q \max }$

Where $\mathrm{Ce}$ is the concentration of $\mathrm{Cu}^{+2}$ ions in the solution at equilibrium, $\mathrm{Q}_{\max }(\mathrm{mg} / \mathrm{g})$ and $\mathrm{b}(\mathrm{L} / \mathrm{mg})$ are Langmuir constants related to the maximum adsorption capacity and the energy of adsorption respectively .A plot of Ce/qe versus Ce should gives a straight line of a slope 1/Qmax and an intercept of 1/b Qmax. Comparison of fitting the Langmuir isotherm equation on the adsorption of $\mathrm{Cu}^{+2}$ ions onto activated carbon and clay is carried out at different temperatures. The Langmuir parameters b, Qmax along with the correlation coefficients are summarized in Table (6). Good fit of Langmuir model on the adsorption of $\mathrm{Cu}^{+2}$ ions onto both clay $\left(\mathrm{R}^{2}=0.96-0.99\right)$ and activated carbon $\left(\mathrm{R}^{2}=0.96-0.99\right)$ is observed.

The results indicated that the Langmuir isotherm is better fitted (Figures (7) and (8)) on the experimental adsorption data of the studied systems than the Freundlich model (Figure (5) and (6)). The maximum capacity of the clay $(\mathrm{Q}=16.12-18.51 \mathrm{mg} / \mathrm{g})$ to adsorb $\mathrm{Cu}^{+2}$ ions is higher than that of the activated carbon used for this study $(\mathrm{Q}=6.84-9.01 \mathrm{mg} / \mathrm{g})$. 


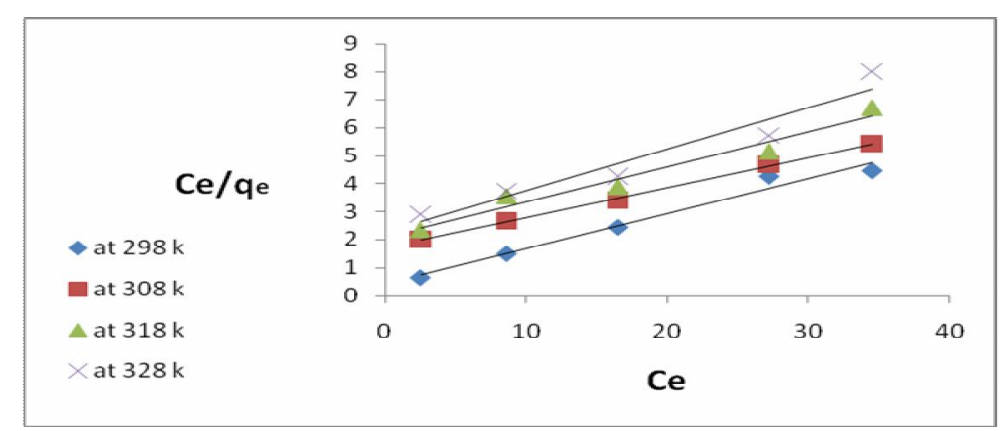

Figures (7): The relationship between Ceq/qe versus Ceq at various temperatures on activated carbon

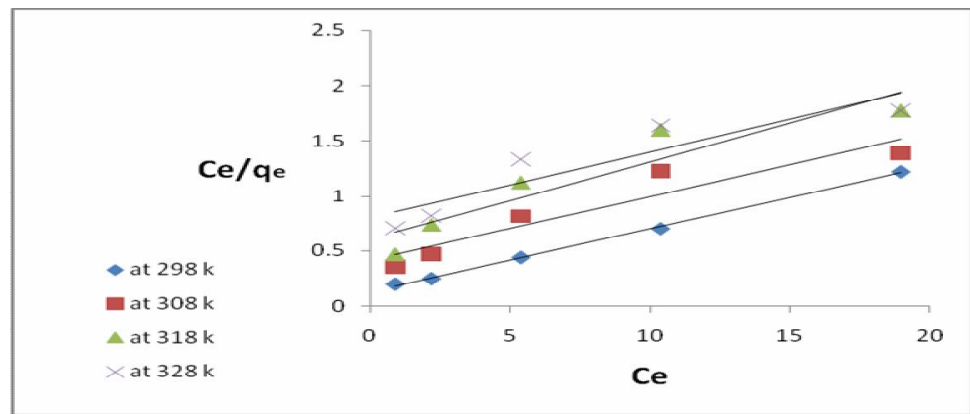

Figures (8): The relationship between Ceq/qe versus Ceq at various temperatures on clay

A dimension less constant termed as separation factor $\left(\mathrm{R}_{\mathrm{L}}\right)$ can be deduced from the Langmuir isotherm data describing the essential characterization of the model relating to the systems under investigation. It can be defined by the following equation:

$$
R L=\frac{1}{1+b C i}
$$

Where $\mathrm{Ci}$ is the initial $\mathrm{Cu}^{+2}$ ions concentration, $\mathrm{b}(\mathrm{mg} / \mathrm{L})$ is the Langmuir constant. According to McKay et al., [22], $\mathrm{R}_{\mathrm{L}}$ value refers to irreversible adsorption process when $\left(\mathrm{R}_{\mathrm{L}}=0\right)$, favorable $\left(0<\mathrm{R}_{\mathrm{L}}<1\right)$, linear $\left(\mathrm{R}_{\mathrm{L}}=1\right)$ or unfavorable $\left(R_{L}>1\right)$. The calculated values of $R_{L}$ for the adsorption data on clay and activated carbon are listed in Table (7). All of the obtained $\mathrm{R}_{\mathrm{L}}$ values are greater than zero and less than unity, showing favorable adsorption of $\mathrm{Cu}^{+2}$ ions on both clay and activated carbon.

Table (7): Values of $R_{L}$ for the two adsorbents at various concentrations and different temperatures

\begin{tabular}{|c|c|c|c|}
\hline Temp ${ }^{\circ} \mathrm{C}$ & $\mathrm{Ci} \mathrm{mg} / \mathrm{L}$ & $\mathrm{R}_{\mathrm{L}}$ (clay) & $\mathrm{R}_{\mathrm{L}}$ (carbon) \\
\hline \multirow{7}{*}{} & 10 & 0.1834 & 0.2531 \\
\cline { 2 - 4 } & 20 & 0.1016 & 0.1450 \\
\cline { 2 - 4 } & 30 & 0.0735 & 0.1015 \\
\cline { 2 - 4 } & 40 & 0.0535 & 0.0781 \\
\cline { 2 - 4 } & 50 & 0.0433 & 0.0635 \\
\cline { 2 - 4 } & 60 & 0.0363 & 0.0534 \\
\hline \multirow{4}{*}{35} & 10 & 0.3378 & 0.5618 \\
\cline { 2 - 4 } & 20 & 0.2032 & 0.3906 \\
\cline { 2 - 4 } & 30 & 0.1453 & 0.2994 \\
\cline { 2 - 4 } & 40 & 0.1131 & 0.2427 \\
\cline { 2 - 4 } & 50 & 0.0926 & 0.2040 \\
\hline
\end{tabular}




\begin{tabular}{|c|c|c|c|}
\hline \multirow{4}{*}{} & 10 & 0.3952 & 0.5714 \\
\cline { 2 - 4 } & 20 & 0.2463 & 0.4000 \\
\cline { 2 - 4 } & 30 & 0.1789 & 0.3077 \\
\cline { 2 - 4 } & 40 & 0.1404 & 0.2500 \\
\cline { 2 - 4 } & 50 & 0.1156 & 0.2105 \\
\cline { 2 - 4 } & 60 & 0.0982 & 0.1818 \\
\hline \multirow{4}{*}{55} & 10 & 0.5154 & 0.5405 \\
\cline { 2 - 4 } & 20 & 0.3472 & 0.3703 \\
\cline { 2 - 4 } & 30 & 0.2617 & 0.2817 \\
\cline { 2 - 4 } & 40 & 0.2100 & 0.2272 \\
\cline { 2 - 4 } & 50 & 0.1754 & 0.1904 \\
\hline
\end{tabular}

\section{Kinetic studied}

The kinetic study of the adsorption of $\mathrm{Cu}^{+2}$ ions on clay is carried out at the natural $\mathrm{pH}$ of the copper ions solutions at various initial concentrations $(10-60 \mathrm{mg} / \mathrm{L})$, and for a period of $(60 \mathrm{~min})$ with time intervals of $10 \mathrm{~min}$. This period is determined from studying the effect of time. The kinetic study was achieved in order to understand the dynamics of adsorption process in terms of the order of rate constant. Information regarding the controlling mechanism of adsorption, such as mass transfer and chemical reaction, which are important for the evaluation of the efficiency of the process, can be provided by such studies.

Pseudo first and pseudo second order models were applied on the adsorption data of the studied system in order to determine the adsorption mechanism and the potential rate controlling steps. The effect of contact time was carried out at various initial concentrations $(10-60 \mathrm{mg} / \mathrm{L})$ and the data were tested to fit two kinetic models selected for achieving the study. The pseudo first order models was described by Lagergren [23] as:

$\operatorname{Ln}\left(\mathbf{q}_{\mathrm{e}}-\mathbf{q}_{\mathrm{t}}\right)=\operatorname{Ln} \mathbf{q}_{\mathrm{e}}-\mathbf{k}_{\mathbf{1}} \mathbf{t}$

Where $\mathrm{q}_{\mathrm{e}}$ and $\mathrm{q}_{\mathrm{t}}(\mathrm{mg} / \mathrm{g})$ are the adsorption capacities at equilibrium and at time $(\mathrm{t})$ respectively, and $\mathrm{k}_{1}\left(\mathrm{~min}^{-1}\right)$ is the rate constant of pseudo first order adsorption. A linear plot of $\operatorname{Ln}\left(\mathrm{q}_{\mathrm{e}}-\mathrm{q}_{\mathrm{t}}\right)$ verses time allows obtaining the rate constant from the slope of the line and $\mathrm{q}_{\mathrm{e}}$ can be calculated from the intercept.

The Lagergren can be considered to be appropriate to the copper ion adsorption on to clay if correlation coefficient $\left(\mathrm{R}^{2}\right)$ close to unity is obtained and the experimental $\mathrm{q}_{\mathrm{e}}$ value is consistent with the value found from the intercept of the plot. Figures (9) and (10) represent the relations obtained from the plot of $\mathrm{Ln}\left(\mathrm{q}_{\mathrm{e}}-\mathrm{q}_{\mathrm{t}}\right)$ against time at different concentrations.

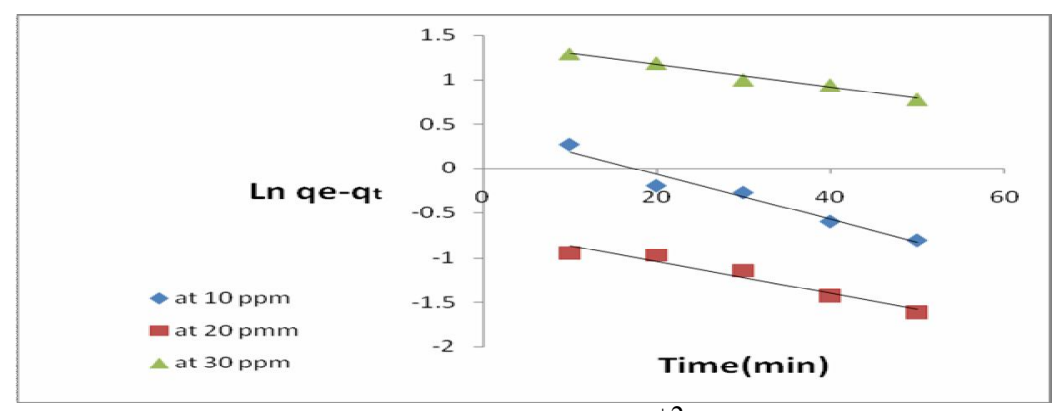

Figure (9): Pseudo first order rate plot for $\mathrm{Cu}^{+2}$ ions adsorption by the clay at various initial concentrations 


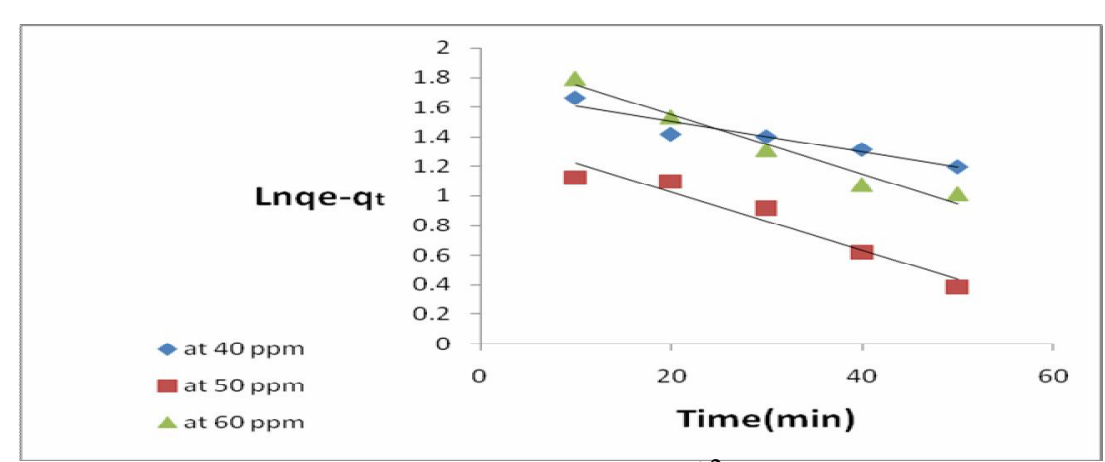

Figure (10): Pseudo first order rate plot for $\mathrm{Cu}^{+2}$ ions adsorption by the clay at various initial concentrations

The values of $\mathrm{k}_{1}$ and $\mathrm{q}_{\mathrm{e}}$ determined from the application of this model on the adsorption data of the studied system are presented in Table (8) along with the corresponding correlation coefficients. It was observed that, the pseudo first order model did not fit well. The values of $\mathrm{R}^{2}$ are far less than unity, and the calculated $\mathrm{q}_{\mathrm{e}}$ did not agree with the experimental $\mathrm{q}_{\mathrm{e}}$ values. This suggests that, the adsorption of the copper ions did not follow first order kinetics.

The pseudo second order kinetic model may be expressed $[24,25]$ as:

$\frac{t}{q t}=\frac{1}{k_{2} q e^{2}}+\frac{1}{q e} t$

Where the equilibrium adsorption capacity $\left(\mathrm{q}_{\mathrm{e}}\right)$ and the second order constant $\mathrm{k}_{2}$ (g/mg.min) can be determined from the slope and intercept of the plot of $t / q t$ versus ( $t$ ) reactively. This model is applicable only when the value of $t / q t$ is linearly correlated with time and the value of the calculated $\mathrm{q}_{\mathrm{e}}$ is well fit the experimental data. The values of $\mathrm{k}_{2}$, experimental $\mathrm{q}_{\mathrm{e}}$ and $\mathrm{R}^{2}$ determined from the application of this model at various concentrations are given in Table (8).

Table (8): Variation of concentration of the ion copper with adsorption capacity

\begin{tabular}{|c|c|c|c|c|c|c|c|}
\hline \multirow{2}{*}{$\begin{array}{c}\text { Conc. } \\
\mathbf{m g} / \mathbf{L}\end{array}$} & \multirow{2}{*}{$\mathbf{q e}(\mathbf{e x p})$} & \multicolumn{2}{|c|}{ First order } & \multicolumn{5}{c|}{ Second order } \\
\cline { 3 - 8 } & $\mathbf{\text { qe }}$ (cal) & $\mathbf{R}^{\mathbf{2}}$ & $\mathbf{q e}(\mathbf{c a l})$ & $\mathbf{R}^{\mathbf{2}}$ & $\mathbf{k}_{\mathbf{2}}$ (g/mg.min) & $\mathbf{h}$ (mg/g.min) \\
\hline 10 & 4.89 & 1.543 & 0.960 & 4.717 & 0.999 & 0.063 & 1.401 \\
\hline 20 & 9.48 & 0.508 & 0.941 & 9.345 & 0.999 & 0.254 & 22.181 \\
\hline 30 & 13.75 & 4.128 & 0.982 & 12.043 & 0.998 & 0.034 & 4.935 \\
\hline 40 & 16.93 & 5.535 & 0.908 & 14.084 & 0.999 & 0.030 & 5.950 \\
\hline 50 & 18.05 & 4.120 & 0.936 & 17.241 & 0.998 & 0.025 & 7.431 \\
\hline 60 & 20.53 & 7.028 & 0.969 & 19.230 & 0.999 & 0.014 & 5.177 \\
\hline
\end{tabular}

The results of Table (8) indicated that, contrary to the first order model, this equation fit the adsorption data well for the whole range of contact time. Excellent linear relationships are obtained (Figures (11) and (12)) indicated by values of correlation coefficients in the range (0.998 -0.999) at all concentrations. 


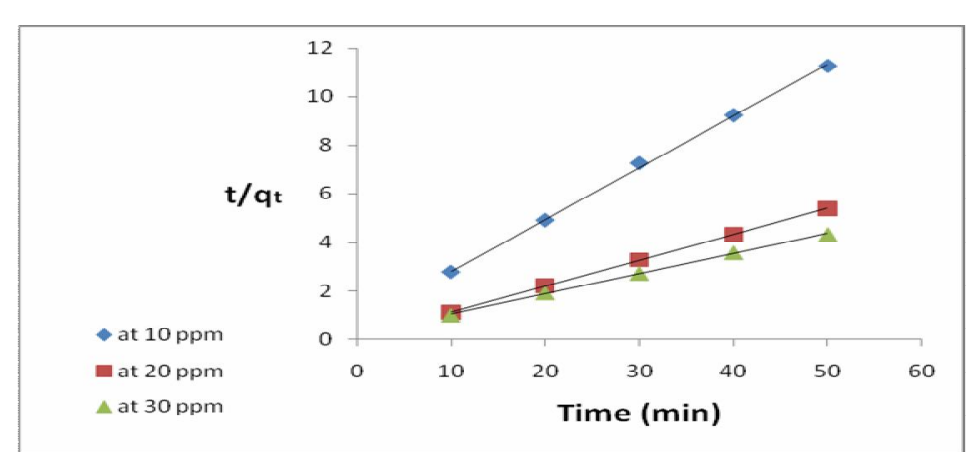

Figure (11): Pseudo second order rate plot for $\mathrm{Cu}^{+2}$ ions adsorption by the clay at various initial concentrations

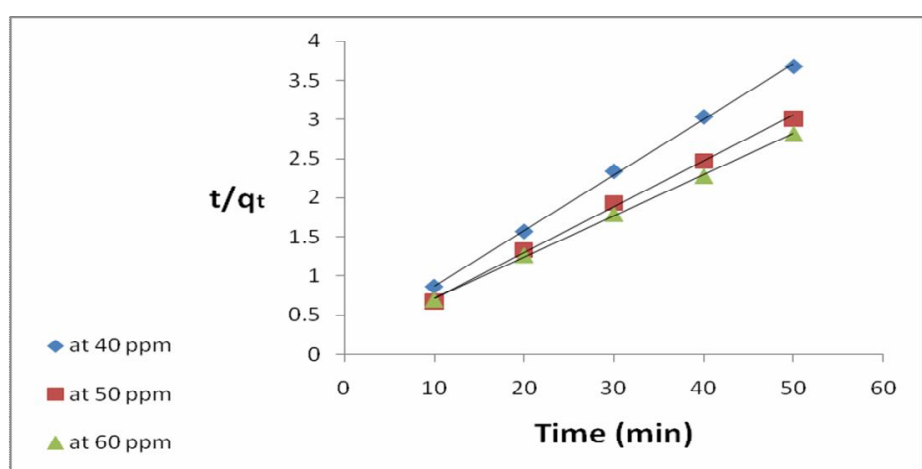

Figure (12): Pseudo second order rate plot for $\mathrm{Cu}^{+2}$ ions adsorption by the clay at various initial concentrations

In addition the values of calculated $\mathrm{q}_{\mathrm{e}}\left(\mathrm{q}_{\mathrm{e}}\right.$ calc.) are agreed well with the experimental $\mathrm{q}_{\mathrm{e}}\left(\mathrm{q}_{\mathrm{e}}\right.$ exp). These results suggest that, the adsorption of the $\mathrm{Cu}^{+2}$ ions onto the selected bentonite obeys the second order kinetic model for the entire period of adsorption based on the assumption that, the rate determining step may involve chemisorptions. The initial rate of adsorption, $\mathrm{h}(\mathrm{mg} / \mathrm{g} . \mathrm{min})$ can be calculated from the pseudo second order model by the following equation:

$$
\mathrm{h}=\mathrm{k}_{2} \mathrm{q}_{\mathrm{e}}^{2}
$$

The results listed in Table (8) showed that, the initial rate of adsorption is increased with increasing the initial $\mathrm{Cu}^{+2}$ ions concentrations. This result is expected due to the increase in driving force at higher concentration. In the same time the increase of initial concentration is accompanied by decrease of the rate constant of adsorption. This could be attributed to that, as time go on, the adsorption efficiency is decreased due to the increase of competition among $\mathrm{Cu}^{+2}$ ions to be adsorbed on the remaining sites on the constant number of active sites available for adsorption on a certain amount of adsorbent. Exception is noticed when $(20 \mathrm{mg} / \mathrm{L})$ initial concentration is used, this could be referred as the optimal initial concentration. 


\section{References}

1) Baran, B.; Erturk, T.; Sarikaya, Y.; Alemdaroglu, T.; Appl. Clay Sci.; 20, 53 (2001).

2) Ozer, M.; Arslan, F.; Onal, G.; key Eng. Mater.; 246 (2004).

3) Molinard, A.; "Physiochemical and Gas Adsorption properties of ion Exchanged alumina pillared clay"; University of Antwerp (UIA); (1994).

4) Ramakrishna, K. R.; and Viraragharan, T.; "Dye Removal using low cost Adsorbents"; Wat. Sci. Tech.; 36, 189-196, (1997).

5) Hedge R. E. M.; and Mclellan M.; Archaeometry; 18, 2, 203, (1976).

6) Wolfrum, C.; and Fritz, P.; "Assessment of experimental research techniques for the investigation of radionuclide migration in aquifers"; Nucl. Sci. Technol.; CEC. Report Eur-13265 EN(1991).

7) Ozdemir, C.; Karatas, M.; Dursun , S.; Argun, M. E.; and Dogan, S.; "Effect of Mnson on the chromium removal from leather industry wastewater"; Environ .Technol.; 26, 397-400 (2005).

8) Meunier, N.; Drogui, P.; Montane, C.; Hauster, R.; Mercier, G.; and Blais, J. F.; "Comparison between electro coagulation and chemical precipitation for metal removal from acidic soil leachate"; J. Hazard. Mater.; 137, 581-590, (2006).

9) Pehlivan, E.; Altun, T.; "The study of various parameters affecting the ion exchange of $\mathrm{Cu}^{+2}, \mathrm{Zn}^{+2}, \mathrm{Ni}^{+2}, \mathrm{Cd}^{+2}$ and $\mathrm{Pb}^{+2}$ from aqueous solution on Dowex 50 W synthetic resin"; J. Hazard. Mater.; B134, 149-156, (2006).

10) Keskinkan, O.; Goksu, M. Z. L.; Basibuyuk, M.; and Foster, C. F.; "Heavy metal adsorption properties of submerged aquatic plant (Ceratophyllum dertersum)"; Bioresour. Technol.; 92, 197-200, (2004).

11) Ghuah, T. G.; Jumasiah, A.; Azni, I.; Katayon, S.; and Thomas Choong, S. Y.; "Rice Husk as a potentially low cost biosorbent for heavy metal and dye removal: an overview"; Desalination; 175, 305-316, (2005).

12) Marquez, G. E.; Riberio, M. J. P.; Ventura, J. M.; and Labrincha, J. A; "Removal of Nickel from aqueous solutions by clay based beds"; Ceram .Int.; 30, 111-119,(2004).

13) Dakiky, M.; Khamis, M.; Manassra, A.; and Mer'eb, M.; "Selective adsorption of Chromium (VI) in industrial wastewater using low 
cost abundantly available adsorbents"; Adv. Environ. Res.; 6, 533540, (2002).

14) Alejandre, A.; Medina, F.; Fortuny, A.; and Sueiras, J. E.; Appl. Catal. B: Environ., 16,(1998).

15) Alvarez, P. M.; Mclurgh, D.; and Plucinski, P.; Ind. Eng. Chem. Res.; 41, 2147, (2002).

16) Pinnavaia T. J.; Tzou, M. S.; Landan and R. Raythata; J. Molecular Catal.; 27, 195, (1984).

17) Egozy, Y.; Clay and Clay Miner.; 28, 314, (1980).

18) Oguz, I.; and Fehmi, A.; " $\mathrm{Cu}$ and $\mathrm{Pb}$ Adsorption on some Bentonite clay"; Turk. J. Chem, 22, (1998).

19) Al-Jawaly, F. E. F.; "Modification of activated carbon for adsorption of heavy metal"; M.Sc. Thesis, Mosul University, Iraq, (2006).

20) Freundlich, H. M. F.; "Uber die adsorption in losungen"; Zeit. Phys .Chem. (Leipzig ); 57A, 385-470, (1906).

21) Lagmuir, I.; "The constitution and fundamental properties of solids and liquids"; J. Am. Chem. Soc.; 38, 2221-2295, (1916).

22) Mckay, G. H.; Blair S.; and Gardiner, J.K.; "The adsorption of dyes onto chitin in fixed bed column and batch adsorbers"; J. Appl. Polym. Sci.; 28, 1499-1544, (1989).

23) Lagergren, S.; "About the theory of so-called adsorption of soluble substances"; K. Sven. Vernskapskad. Handl.; 24(4), 1-39, (1898).

24) Ho, Y.S.; Wase, D.A.; and Forster, C.F.; "Kinetic study of competitive heavy metal adsorption by sphagnum moss peat"; Environ. Technol.; 17(1), 71-77, (1996).

25) Mckay, G.; and Ho, Y.S.; "Pseudo second order model for adsorption process"; Process. Biochem.; 24, 451-465, (1999).

26) Ofomaja, A. E.; Naidoo, E. B.; and Modise, S. J.; "Removal of copper (II) from aqueous solution by pine and base modified pine cone powder as biosorbent"; J. Hazard. Mater.; 168, 909-917, (2009).

27) Al-Abady, Ra'ed T. G.; "Thermodynamic and kinetic study of adsorption of di azo dyes on activated carbon in aqueous solutions"; Ph.D. Thesis; College of Education, Uni. Mosul, 2010. 